\title{
Social Position and Direction of Maritime Society Transformation (Case Study on Community Community Maritime Affairs Bugis Makassar South Sulawesi)
}

\author{
Eymal B. Demmallino ${ }^{1}$, M. Saleh S. Ali ${ }^{1}$, Abd. Qadir Gassing ${ }^{2}$, Munsi Lampe ${ }^{3}$, La Nalefo ${ }^{4}$, Sri Rezki Eskawaty \\ Rosmala $^{5} \&$ Bahtiar $^{6}$ \\ ${ }^{1}$ Department of Social Economics of Agriculture, Hasanuddin University, Indonesia \\ ${ }^{2}$ Alauddin Islamic State University, Makassar, Indonesia \\ ${ }^{3}$ Department of Anthropology, Faculty of Social and Political, Hasanuddin University, Indonesia \\ ${ }^{4}$ Department of Social Economics of Agriculture, Halu Oleo University, Indonesia \\ ${ }^{5}$ Postgraduate Student, Master of Management, Padjajaran University, Bandung, Jawa Barat, Indonesia \\ ${ }^{6}$ Department of Sociology, Faculty of Social Political, Halu Oleo University, Indonesia \\ Correspondence: Eymal B. Demmallino, Department of Social Economics of Agriculture, Hasanuddin \\ University, Indonesia. E-mail: demmallino1964@yahoo.com
}

\author{
Received: July 26, 2016 Accepted: October 12, 2016 Online Published: February 3, 2017 \\ doi:10.5539/jsd.v10n1p1 URL: http://dx.doi.org/10.5539/jsd.v10n1p1
}

This paper is the fourth series of the fifth or sixth series of planned, all of which are extracted and developed from the results of the study lead author of the dissertation entitled Socio Cultural Transformation: Initiating Community Renewal Maritime Affairs Bugis Makassar in South Sulawesi are strengthened with further study together with co-authors with titles: Siratal Mustaqim: Poverty Alleviation Efforts initiated the Maritime Society in its South Sulawesi.

\begin{abstract}
The study aimed to analyze the social position of the maritime community in the context of maritime economic behavior and attempt to determine the direction for socio-cultural transformation in an effort to build a maritime civilization in State Bugis Makassar South Sulawesi. This study uses Verstehen (qualitative interpretative) to the maritime community's social position and the possibility of choice over the direction of its transformation process. The results showed that the social position the maritime community in the position marked with the mentality of economic behavior kelemah adab $\sim$ karsaan, where on the one hand weak capital owners tend to behave in manners (exploit workers) as a consequence of the influence of capitalism and on the other, workers tend to behave weak intention (not productive, excessive dependence $\sim$ resigned, and consumptive life style) as a consequence of the influence of classical Sufism. Worsened by the presence of modernization (acceleration technology $\sim$ carbide) that are not relevant to the potential maritime and impartiality of policy makers resulting in further social pathology (each claimed), environmental destruction, and the destruction of the local culture. This study merekomendir necessity of directing the transformation of socio-cultural community of the maritime community in efforts to grow $\sim$ develop economic behavior that mentality kekuat adab $\sim$ karsaan as a major foundation in building a maritime civilization. In this effort the government alignments and selection of appropriate technologies to realize it is absolutely necessary.
\end{abstract}

Keywords: mentality, economic behavior, technology options, alignments, position and socio cultural transformation

\section{Prolog}

\subsection{Objective Considerations (Series Writing Previous Findings)}

The first article (entitled: Capitalism and Economic Behavior Society Maritime, A Case Study of the Pasompe' Community in the Bugis Makassar Land of South Sulawesi, Demmallino, at al, 2016: 44-54), and the second article (entitled: Sufism and Economic Behavior Society Maritime Case Study on Pakkaja Community in South 
Sulawesi, Demmallino, at al, 2016: 136-146), from the previous series of the authors find that the maritime community in the State Bugis Makassar South Sulawesi are under the influence of Western capitalism $\sim$ Secular particularly among owners of capital (bourgeoisie) and the influence of classical Sufism in particular for most workers (proletariat). Thus the socio-economic structure of the maritime community in the State Bugis Makassar South Sulawesi until today is still characterized by so-called economic dualism: a static economic system that absolutely can not be expected to build a maritime civilization (Boeke, 1905 in Soewardi, 1995: 5).

Other findings elaborated at the third article (entitled: Policy and Maritime Society Underdevelopment Case Study on Community Maritime Affairs Bugis Makassar South Sulawesi, Demmallino, at al, 2016: 144-150). The inscription on this article confirms that the backwardness of the maritime community today is also falling through the cracks caused by the government since the republic (of independence), especially in the era of Soeharto administration (new order), or what is more popularly called turning away government policy from sea to land. Although it was realized that there is actually a maritime efforts undertaken in the Soeharto era, known as the blue revolution, but the effort - an effort in which more reflects the transfer of technology, such as: accelerating growth of shrimp and fish are done through INTAM Program (Intensification Pond) at Community Pallawa and acceleration of shipping is done through the Community Programme on Pakkaja Motorization and Pasompe, but both ended up with social patalogi (each claimed), environmental destruction, and the destruction of cultural locality (traditional navigation) as the only one of the most valuable assets and national pride.

\subsection{Questions and Research Objectives (Where and Where Should There should)}

Based on the findings presented in the three above-mentioned article, the research question: in which the social position of the maritime community located (existence) within the framework of theory Adab $\sim$ Karsa (Soewardi, 1995) and should be where we are heading (where the direction of its transformation) in creating a maritime civilization The State Bugis Makassar South Sulawesi, especially within the framework of Development Modernization Theory (Ramos in porcelain and Totten, 1985). A new version of modernization that contradicts the version of modernization which we understand or what is commonly understood by the term Europeanization. The purpose of research is to find the position and direction of the transformation right in building maritime civilization.

\subsection{Theoretical Grounding (Theory of Adab Karsa and Modernization Development)}

This research use theory of transformation was initiated by Herman Soewardi (1995: 1: See Figure 1), a social theory that is not only intended to explain the actual position of society in the context of the change but also at the same time intends to move forward by showing the direction of a social change desired. Such a theory is more accurately called Prophetic Social Theory (Kuntowojoyo, 1991: 288). Soewardi call this transformation theory under the name Theory of Adab $\sim$ Karsa, a theory of civilization is lifted from the development of world civilization, particularly the Islamic civilization had triumphed over more than six centuries (VII $\sim$ XIII century AD), a civilization that was pioneered by the Prophet Muhammad (VI century AD) in building "Capitalism civilization", unprecedented anywhere in the world. 


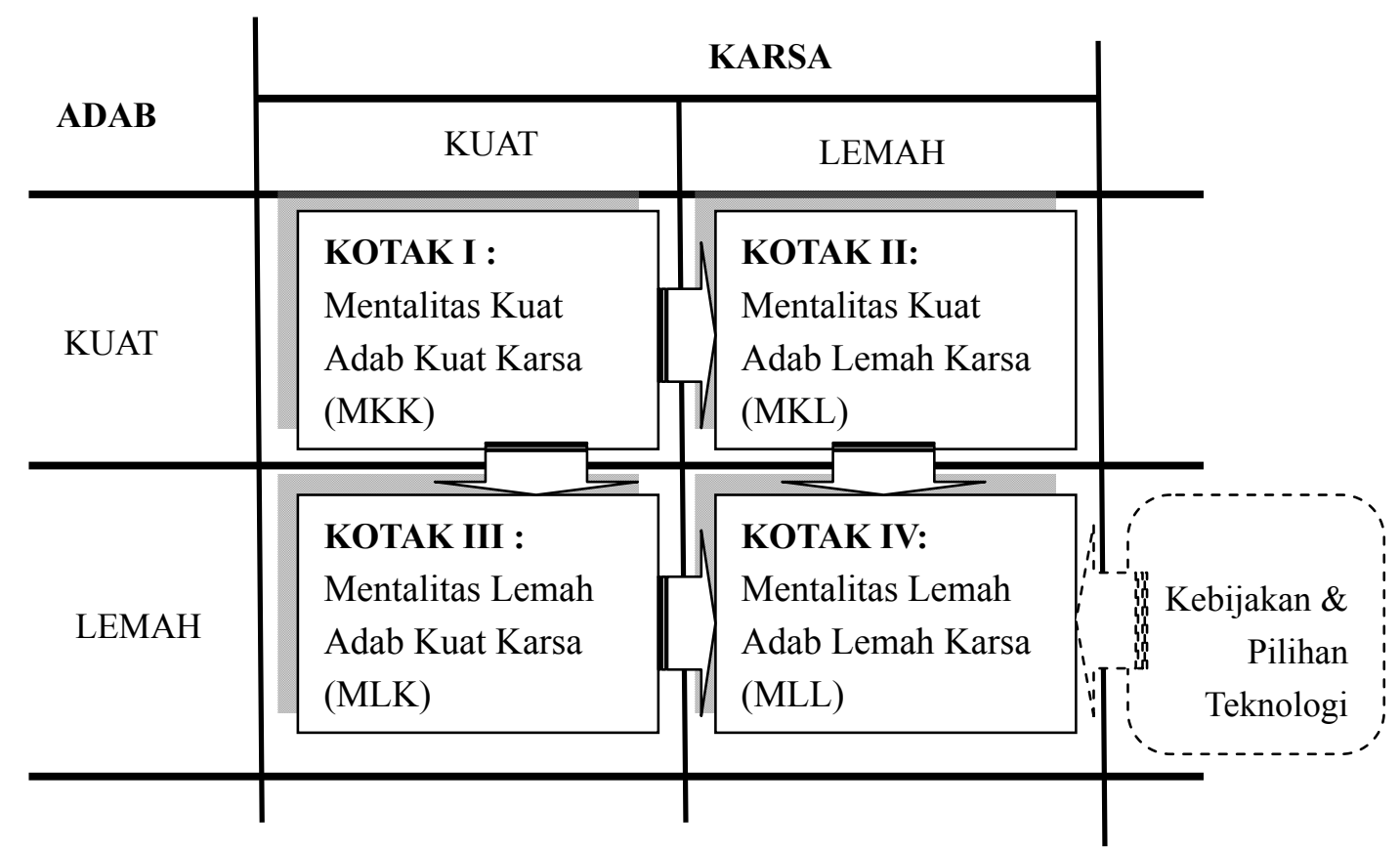

Figure 1. Theory of Adab Karsa (Herman Soewardi, 1995) and Theory of Modernization (Ramos, in Beling and Totten, 1985)

Placed in Modernization Theory Development Framework (Ramos in Beling and Totten, 1985) relating to policy (partisanship) and Option Technologies, Theory of Adab $\sim$ Karsa mentioned above seems to pay less attention to or ignore the policy aspect (alignments) and the choice of technology as something that also important take effect on maritime community retardation. In this study both the theory juxt aposed in an effort to illuminate aspects of the structural and cultural communities that make maritime retarded (See Figure 1).

\section{Research Methods}

The study uses a method of understanding (Verstehen, Weber in Ritzer and Goodman, 2004 and Kaelan, 2005) or the so-called "object intentionality" (Berger, 1967) to what is found in a study of capitalism, Sufism, and policies towards the maritime community retardation the State Bugis Makassar South Sulawesi $\sim$ as has been described in Article First, Second, and Third briefly and substantially raised in advance on the objective consideration. This study concludes with reflective thinking, namely pengintuisian on the essence of the object being studied or rather the position and direction of the transformation of the socio $\sim$ cultural maritime community (Husserl, in Zubaedi, 2007: 121-134). Including theoretical reflection and policy implications. The research conducted at the Maritime Society Community in South Sulawesi by selecting cases in the District Pangkep Pallawa Community, Community Case Pakkaja in Takalar, and Community Case Pasompe in Bulukumba.

\section{Position and Direction of Social Transformation Maritime Society}

\subsection{Social Position of the Maritime Society (The Existence of Community Maritime Affairs Bugis Makassar)}

Based on data as stated in the first article, it was found that there is a striking difference revenue of the using Rules for Profit Sharing with the use of Profit Sharing Regulations in income distribution in the Pakkaja Community. If the intended net revenue based on the Rules for Profit Sharing is Rp 4,917,672 per catching per year, then the results (revenues) received by Leader on land is Rp 2,950,603, - per catching per year $(60 \%)$ and part results received by Sea Leader (Ponggawa Laut) and the crews, it is Rp 1,967,069, - per catching per year (40\%), see Table 1. But if using Fisheries Regulations for Profit Sharing, then of acceptance of Rp 4,917,672 per catching per year, while Leader on land only received part of Rp 1,950,899, - per catching per year and Sea

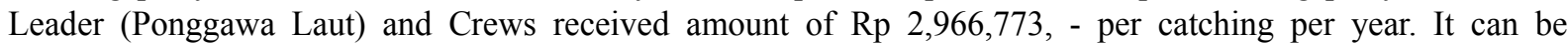
concluded that the Pakkaja Community of the exploitation of Rp 999 704, - per catching per year (See Table 2). If in a month occurred 3 - 4 times the period of catching, the massive exploitation of the Pakkaja Community can reach $\mathrm{Rp} 2,999,112$, - up to $\mathrm{Rp} 3,998,816$, - per month and if within a year the average catching reached 79 times, then the amount of exploitation is around $\mathrm{Rp} 75,977,504$ per year. 
Table 1. Average distribution of profit sharing in community Pakkaja in last 10 years (2005-2014)

\begin{tabular}{llll}
\hline $\begin{array}{l}\text { Distribution Rules of local } \\
\text { profit sharing }\end{array}$ & $\begin{array}{l}\text { Net Receipts } \\
\text { /Catching) }\end{array}$ & $\begin{array}{l}\text { Rp } \\
\text { Catching) }\end{array}$ & \begin{tabular}{l} 
(Rp./Catching) \\
\hline $\begin{array}{l}\text { 1. Rules For Local Results } \\
\text { 2. Regulations of profit } \\
\text { sharing }\end{array}$
\end{tabular} \\
$\begin{array}{l}4.917 .672,- \\
\text { 3.Magnitude Exploit }\end{array}$ & $2.950 .603,-$ & $1.967 .069,-$ \\
\hline
\end{tabular}

Source: Data 10 years of Pakkaja Community

Table 2. Income distribution based on law for the Pakkaja community

\begin{tabular}{|c|c|c|}
\hline Status in Leadership & Section Results / Catching (Rp) & Profit Sharing/ Month (Rp) \\
\hline 1. Leaders on land & $692.714,-$ & 2.078.142,- \\
\hline 2. Leaders at sea & $470.396,-$ & 1.411.188,- \\
\hline 3. Lights Crew & $264.598,-$ & 798.394,- \\
\hline 4. Nets Crew & $226.798,-$ & $680.395,-$ \\
\hline 5. Machinery Crew & $226.798,-$ & $680.395,-$ \\
\hline 6. Common Crew & 151.198,- & 453.596,- \\
\hline Average & 338.750,- & 1.017.018,- \\
\hline
\end{tabular}

Source: Data Average Income Distribution in the last 10 years

Prom Pakkaja Community (2005-2014).

Through the transferability test also found that the Pallawa and Pasompe Community, exploitative acts of exploitation also occurs even magnitude is much greater than the exploitation that occurred in the Pakkaja Community. The Community scale exploitation of Pallawa Community average reached Rp 60.458.644.- per harvest per year, or approximately Rp 120.917.229. - per year. Greater on Pasompe Community, where the amount of exploitation can reach Rp 166462 142, - per route cruise year. If in a year were able to complete four Pasompe Community route shipping within at least six months, then the amount of exploitation can reach $\mathrm{Rp}$ 665848568 , - per year. The magnitude of this exploitation is concerned directly with the amount invested Land Leader (Ponggawa Darat) in their maritime business. The scale of investment in the Pakkaja Community can reach Rp 1.3 billion, the amount of the investment Pallawa community can reach Rp 2.1 billion and the Pasompe Community amount of investment could reach US \$ 3.3 billion, see Table 3 in advance. In other words, the greater the investment in the maritime community, the greater the exploitation Land Leader (Ponggawa Darat) to the Sea Leader and the Crews. This exploitation is very aware of the Sea leader and the Crews. The realization often expressed: "Katte paboyayya nampai allampa nicukkuru 'maki, ammoterekki sallang nigondolo'ki Poeng, Katte finger paboyayya kaddaro' namami kigappa, sakamma kammanami anjo paboyayya Katte" (We workers just about to go shaved saddled with operating costs, return again saddled with other costs, so that we workers get only "remnants" results of operations alone, that the fate of our workers).

Table 3. Comparison amount of investment and exploitation in maritime communities

\begin{tabular}{llll}
\hline \multirow{2}{*}{ Communities } & Investment value (Rp) & Magnitude Its Exploitation (Rp) & \\
\cline { 3 - 4 } & & Per Unit & Per Year \\
\hline 1. Pakkaja & 1.3 billion & $999.773,-/$ catching of one boats unit & $\begin{array}{l}75.977 .594,-(79 \times \text { catching of three boats } \\
\text { unit }\end{array}$ \\
2. Pallawa & 2.1 billion & $60.458 .644,-/$ Harvest & $120.917 .229,-(2 \times$ Harvest $)$ \\
3. Pasompe & 3.3 billion & $166.462 .142,-/$ the cruise route & $665.848 .568,-(4 \times$ the cruise route) \\
\hline
\end{tabular}

Source: 10 Years of the respective each Community, Maritime Society (2005-2014). 
The study also found that actually means even if there is no exploitation, maritime community especially in the Pakkaja Community, they remain poor. By using the rules of Islam though (System Qiradh $=50: 50 \%$ ) in the distribution of their income, what is gained Land Leader (Ponggawa Darat) looks indeed smaller than when using of Profit Sharing Regulations, which amounted to Rp 692,713.95, - per catching per week $(\operatorname{Rp} 6,383,949$, 2: $2=3,191,974.95$ to $2,499,261=692,713.95)$ or a maximum of only $R p 2,078,141.85$, - per month. Instead Sea Leader (Ponggawa Laut) and the Crews gain a larger share compared with the use of Profit Sharing Regulations, which increased to RP 3,191,974.95 per catching per week, but the portions were obtained by Sea Leader (Ponggawa Laut) remains low, at only Rp 470,396.3, - per catching a week or a maximum of Rp 1,411,188.9 per month. Moreover the lamp operator crew only get part amount Rp 264,597.92 per catching per week or amount Rp 793,793.75, - per month, Interpreter Nets Crew only get part about Rp. 226,798.215, - per catching per week or amount Rp 680,394.645, - per month, Saviour Machine Crew only get part amount Rp 226,798.215 per catching per week or Rp. 680,394.645, - per month, and Ordinary Crew only received part amount Rp.151,198.81, - per catching per week or amount Rp. 453,596.43 per month. Condition of the result (acceptance) Sea Leader and the Crews in the above mentioned of Pakkaja Community still very far from the Standard Wage of South Sulawesi Regional (2014), which amounted to Rp 72,000 per day or Rp 1.800.000, - per month.

The findings above indicate that in addition to structural factors (exploitation), there is also another factor that is even more dominant influence on the impoverishment of the maritime community, namely low productivity. In the maritime community terms of productivity or results of operations is always interpreted the same as the "dalle" (provision) which has been determined by God for each of his servants. Therefore when they were asked why their labor is low, then the answer is "battuji ridalleka" (depending sustenance of God). For them a number of views here are very concerned with productivity has remained coloring ideology, thought, and behavior of their economies:

"Nia' tau nia' mentong dalle'na nisaraengi ri Allah Ta'ala, nia' tong tena manna poso abboya" (sometimes there are people indeed were given in abundance of Allah Ta'ala, but otherwise no one was not given any sustenance at all, even though they are working hard to look for).

"Sampang sikankang, sikankang tonjintu nugappa, punna labbii, takkebai" (if sustenance for everyone just a handful, then no more than that you can get, if so will certainly be wasted or move on to someone else).

"Punna se'reji dalle'nu glasses, sikamma tonjintu nugappa, mannako poso usah" (if you are just a glass of sustenance, just as much as that's all you can get, even if you have been trying with difficulty).

"Manna bassi nibuang reje'neka ammawanji” (walau besi dibuang ke air bisa terapung : kalau memang rezki kita pasti kita dapat memperolehnya) (If iron dumped into the water can float : if indeed our sustenance surely we can obtain it)"Manna taluttu'ja nibuang rije'neka laburu'ji" (walau kapas dibuang ke air bisa tenggelam : kalau bukan rezki kita tetap saja kita tak dapat memperolehnya). (Although cotton discharged into water can sink: if not sustenance we still we can not get it)

"Punna lebba' tommaki anggaukangi tenamo nani sassala' kalenta, terseramami katte ri Allah Ta'ala" (bila telah diusahakan, kita tidak akan menyesal, cukuplah kita berserah diri kepada Allah Ta'ala) (When it has been cultivated, we will not regret, it is enough we surrendered to Allah Ta'ala)

"Manna nitunggeng atau nipatuntung uluyya a'boya umpai teayai dalle'ka, mustahele'ji”" (walaupun kepala kita miringkan atau di bawah sekalipun dalam bekerja atau berusaha, kalau bukan rezki kita, mustahil kita dapat memperolehnya). (Although we head tilt or below even in work or trying to, if not our sustenance, it is impossible we can obtain it).

The phrase or idea (ideology) maritime community implies that they are in business is highly dependent or put excessive reliance on God or what is in the schools of Sufism Classical called Theology of the Will of the Absolute God, a theology of resignation that apparently can not be used as a reference in economic activity because of ideology this leaves no room at all for a person endeavor in particular relating to: hard work, science, and technology. Thus the cultural factors, especially those stemming from the "understanding" of classical Sufism in the maritime community (especially those of the Community Pakkaja) is more dominant influence on their impoverishment.

Placed within the framework of theory Adab Karsa, then the economic dualism that is still plagued maritime community shows that the position of civil society in the State maritime Bugis Makassar is the fourth box, a box that indicates that the maritime community is located in two large influence, the influence of Western capitalism 
$\sim$ Secular and Classical Sufism influence (Islamization Nusantara) into Indonesia in medieval (XIII century AD). Effect of exploitative capitalism is shown by the behavior of the owners of capital both to workers, the environment, and to the maritime culture $\sim$ as has been discussed in the first article, was the influence of classical Sufism is shown in low productivity, excessive dependence and consumptive lifestyles particularly among workers. Referring to the theory of manners $\sim$ intention then exploitative behavior was seen as the fruit (consequences) of mentality kelemah $\sim$ adaban or mentality loose horse stables (Soewardi, 1995) or mentality bypass (Koentjaraningrat, 1983), was low productivity, excessive dependence, and style consumptive life is seen as the fruit of mentality kelemah $\sim$ karsaan. Thus the economic behavior menggorogoti socio-economic structure of society in the State maritime Bugis Makassar South Sulawesi is seen as a consequence of mentality kelemah adab $\sim$ karsaan, a mentality which can not be expected in a building of maritime civilizations in the future.

Along with the development of maritime modernization (particularly the choice of technology) that are not rooted in the local maritime culture and impartiality of government during the period of the new order, requires the owners of capital to further improve the investment itself, which was then on the one hand to expand the scale of business or there appears to be progress but on the other hand even more to give increasingly wide space for the flourishing of exploitative behavior, not only from the owners of capital to workers, even just the opposite has occurred; a social pathology as indicated by the behavior of each wrench. When the owners of capital tightening system for the results with the aim to accelerate the process of investment, on the contrary among workers doing the sale of fuel at sea or without the knowledge of the owners of capital, by reason of the results of operations when it is not enough to be divided. Grabbed each other's behavior like this in the local parlance is called "Silukkakki".

In view of Ramos (in Beling and Totten, 1985), modernization of maritime tangible like this can not be categorized as modernization, especially the choice of technology used did not bring increased prosperity for the workers. In other words, the blue revolution program was originally initiated by the government can be said to be a total failure. The cause is on the one hand due to the impartiality or that the government is on the development maritime and on the other hand because of the choice of technology used is not interconnectivity (Makagiansar, 1997) or stature (Don Ihde in Lim, 2008) with the potential and the local maritime culture, or unfriendly environmental and human-faced or not (Schumacher, 1979).

\subsection{Directions Transforming Society Maritime (There Should Where Should Step)}

By finding and understanding the social position of the maritime community in Box IV (the Framework Theory of Adab $\sim$ Karsa) or so-called civilized mentality kelemah $\sim$ adab $\sim$ karsaan, a social pathology that gnaw socio-economic structure of the maritime community and the neglect of them during the period of the New Order government, then now the question that must be answered is how to cure diseases such mentality. But before answering that question in this article must first select or determine the direction of curing disease is the mentality of society. Efforts to cure diseases such mentality, specifically will be discussed in the next article.

With reference to the Theory of Adab $\sim$ Karsa, then there are at least three directions for healing or rather the socio-cultural transformation of the maritime community to choose from. The first option is to Box Into Civilization III : Secular Western Box arguing that Ponggawa Besar generally and some Ponggawa Kecil Maritime Communities have had the mentality kekuat $\sim$ karsaan at risk will continue to experience side effects (exacerbating the disease mentality kelemah $\sim$ adaban). The second option is to Box Into Civilization II: Age of Colonialism Box Muslim Indonesia (medieval) on the grounds that most of the Maritime Society Community (especially at the Community Pasompe) also has the mentality kekuat $\sim$ adaban (in the sense of Theology Will of the Absolute God), but with risks will experience side effects (exacerbating the disease mentality kelemah karsaan particularly at Community Pallawa and Pakkaja). A third option is to Box Civilization I: Box Muslim Classical Age, a box that is considered the most perfect civilization, namely the mentality Box Kekuat $\sim$ Adab Karsaan (See Figure 2).

Box Civilization I : Box Classical Muslim civilization is a box that in view Kuntowijoyo (2008) inherited the Greek $\sim$ Roman civilization in the West and the civilization of Persia, India, and China in the East. When the two civilizations were drowned and suffered setbacks, Islam is growing and evolving take on the role as the main heir and lasted for approximately $6 \sim 8$ centuries. Islamic civilization is initiated and successfully practiced by the Prophet Muhammad in Medina (Capital Power Islam First). Robert N. Bellah (in Laode Kamaluddin, 2008) clearly states: in the hands of Muhammad, the people of Medina who had primitive "transformed" into a very modern society. From here then followed by friends (Khalifah Rasulillah) through the expansion and development of power by build Kufah (Capital Power Islam Second). The next generation followed by a massive expansion undertaken by the Umayyad Caliph, based in Damascus (Capital Power Third Islamic) VI $\sim$ VII 
century AD and Islam reached its peak in the hands of the Abbasid Caliph in Baghdad centered (Capital Power Fourth Islamic) VII $\sim$ XIII century AD, as well as three Islamic empire later that still survive politically until the eighteenth century (Turkey, Persia, and India), though greatness is not comparable with the previous caliphs.

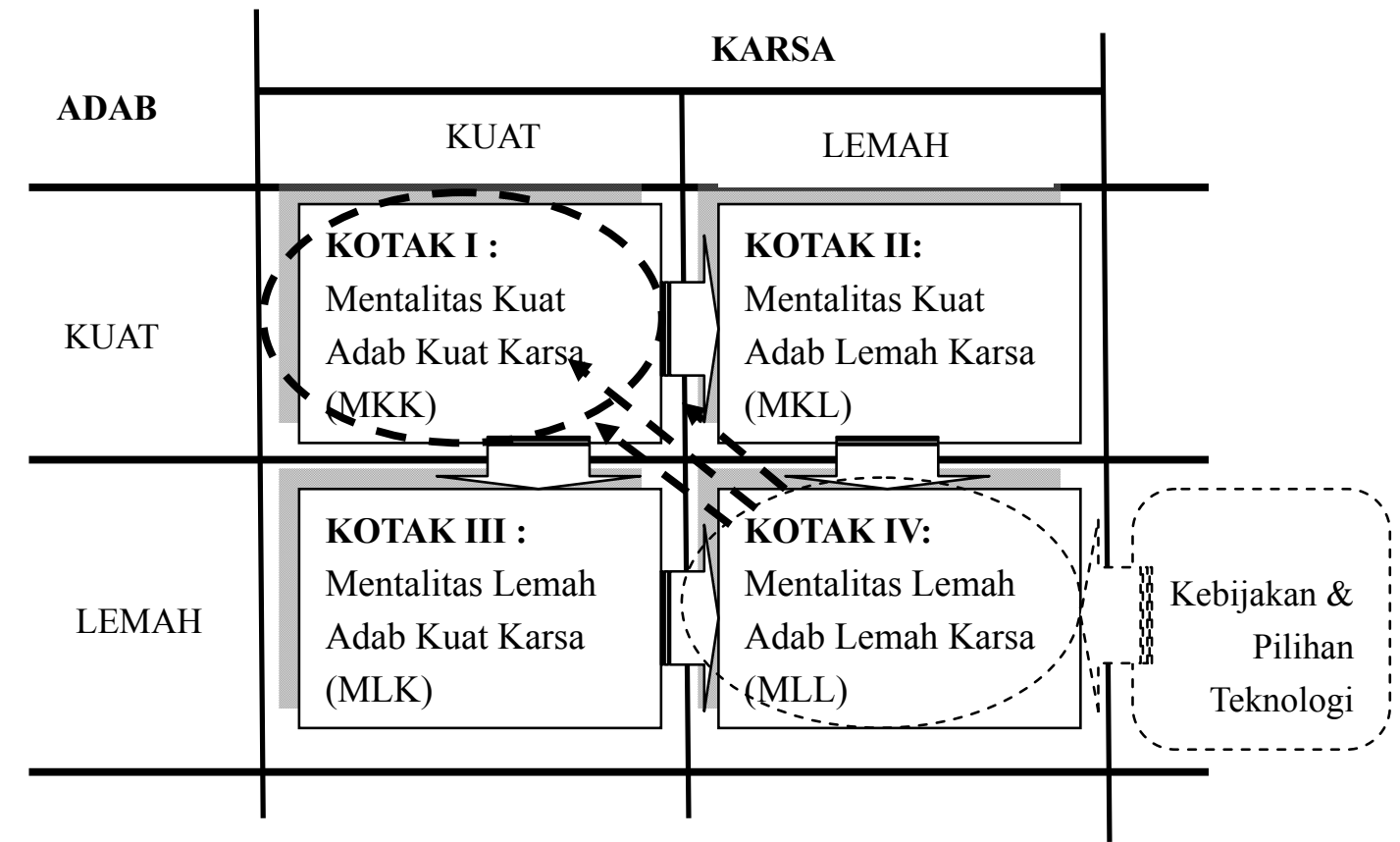

Figure 2. Position and direction of social transformation cultural society maritime affairs Bugis Makassar in South Sulawesi

Thus the most appropriate choice as socio-cultural transformation in curing diseases maritime community mentality in Country Bugis Makassar South Sulawesi is in Box Civilization I: box mentality kekuat adab karsaan or the inverse of the box mentality kelemah adab karsaan as contained or is found in Box civilization IV. Now the question: How to encourage maritime community mentality from box to box Civilization IV Civilization I and ideas as to what is needed. The answer once again be specifically discussed at the Fifth Article (series next article).

\section{Epilog: Theoretical Reflection and Policy Implications}

Theoretically, these findings strengthen and clarify "economic dualism" found Boeke in dissertation studies in Java. A socio-economic structures that do not support each other and then exacerbated by the presence of modernization in the form of technological options that are not relevant and impartiality on the part of policy makers. This condition is in its development increasingly make space for the flourishing of mentality kelemah adab $\sim$ karsaan which then puts the maritime community in Box IV Position in Theoretical Adab $\sim$ Karsa ; a very social position can not be expected to develop their maritime civilization.

Furthermore, in an effort to transform the socio-economic structure of the maritime community, which is still located in Box IV as an effort to break free from the influence of capitalism and classical Sufism, this study recommending to drive transformation in Box I : Box mentality Strong Society Adab Karsa $\sim$ as has been successfully implemented by the caliphs in building the Islamic civilization; a civilization quite successful and longest in the history of world civilization (six to eight centuries). In an effort to encourage socio-cultural transformation of Box IV to Box I, the government partisanship mutlah required, both in terms of policies, programs, and technology choice.

\section{References}

Demmallino, E. B. et al. (2016a). The Capitalism and Economic Behavior of the Maritime Community A Case Study of the Pasompe' Community in the Bugis Makassar Land of South Sulawesi. Journal of Sustainable Development, 9(1), 44-54. https://doi.org/10.5539/jsd.v9n1p44

Demmallino, E. B. et al. (2016b). Sufism and Behavior of Maritime Economic Community (Case Study on Pakkaja Community in South Sulawesi). Journal of Sustainable Development, 9(3), 136-146. 
https://doi.org/10.5539/jsd.v9n3p136

Demmallino, E. B. et al. (2016c). Policy and Backwardness of Maritime Society Case Study on Community Maritime Affairs Bugis Makassar South Sulawesi. Journal of Sustainable Development, 9(4), 144-150. https://doi.org/10.5539/jsd.v9n4p144

Demmallino, Eymal B. (1988/2011). Transformasi Sosio-Kultural : Menggagas Pengembangan Masyarakat Maritim di Negeri Bugis $\sim$ Makassar Sulawesi Selatan (Disertasi Doktor Program Pascasarjana Konsentrasi Sosial Ekonomi Pertanian UNHAS : 2006 2011).

Demmallino, Eymal B. dkk. (2016). Siratal Mustaqim: Menggagas Upaya Pengentasan Kemiskinan Masyarakat Maritim di Sulawesi Selatan. Makassar: Kerjasama LPPM UNHAS dengan Direktorat Jenderal Perguruan Tinggi Departemen Pendidikan Tinggi, Riset, dan Teknologi Republik Indonesia.

Hamid, A. (2005). Pasompe: Pengembaraan Orang Bugis. Makassar : Pustaka Refleksi.

Kaelan. (2005). Metode Penelitian Kualitatif Bidang Filsafat: Paradigma Bagi Pengembangan Penelitian Inter-disipliner Bidang Filsafat, Budaya, Sosial, Semiotika, Sastra, Hukum dan Seni. Yogyakarta: Paradigma.

Kamaluddin, L. (2008). Rahasia Bisnis Rasulullah: 12 Rahasia Besar Kepemimpinan Rasulullah dalam Membangun Megabisnis yang Selalu Untung Sepanjang Sejarah. Semarang: Wisata Ruhani Pesantren Basmala.

Koentjaraningrat. (1983). Kebudayaan Mentalitas dan Pembangunan. Jakarta: Gramedia.

Kuntowijoyo. (1991). Paradigma Islam: Interpretasi untuk Aksi. Bandung : Mizan.

Lim, F. (2008). Filsafat Teknologi Don Ihde tentang Dunia, Manusia, dan Alat. Yogyakarta: Kanisius.

Makagiansar, M. (1997). Meneropongi Perguruan Tinggi Indonesia dalam Dunia yang Saling Ketergantungan dan Senantiasa Penuh Perubahan. Makassar: Orasi Ilmiah Disampaikan pada Dies Natalis ke 41 UNHAS pada Tanggal 10 September 1997.

Miles, M. B., \& Huberman, A. M. (1992). Analisis Data Kualitatif. Jakarta: Indonesia University Press.

Myrdal, G. (1981). Objektivitas Penelitian Sosial. Jakarta : LP3ES.

Ramos, A. G. (1980). "Menuju Suatu Model Kemungkinan" dalam W.A. Belling dan G.O. Totten, Modernisasi : Masalah Model Pembangunan. Jakarta : YIIS.

Ritzer, G., \& Goodman, D. J. (2004). Teori Sosiologi Modern. Jakarta : Kencana.

Schumacher, E. F. (1979). Kecil Itu Indah: Ilmu Ekonomi Yang Mementingkan Rakyat Kecil. Jakarta: LP3ES.

Soewardi, H. (1995). Transformasi Agraris-Industrial di Indonesia: Suatu Pendekatan Sosiologis. Makalah. Bandung.

Soewardi, H. (1996). Nalar, Kontemplasi dan Realita. Bandung : Pascasarjana UNPAD.

Syam, F. (2009). Membangun Peradaban Indonesia: Renungan B.J. Habibie. Jakarta : Gema Insani.

Weber, M. (2006a). Sosiologi. Yogyakarta: Pustaka Pelajar.

Weber, M. (2006b). Studi Komprehensif Sosiologi Kebudayaan. Yogyakarta: IRCiSod.

Zubaedi. (2007). Filsafat Barat: Dari Logika Baru Descartes hingga Revolusi Sains ala Thomas Kuhn. Yogyakarta: Ar-Ruzz Media.

\section{Copyrights}

Copyright for this article is retained by the author(s), with first publication rights granted to the journal.

This is an open-access article distributed under the terms and conditions of the Creative Commons Attribution license (http://creativecommons.org/licenses/by/4.0/). 